\title{
Osuwiska w Sudetach
}

\author{
Rafał Sikora $^{1}$, Tomasz Wojciechowski ${ }^{1}$
}

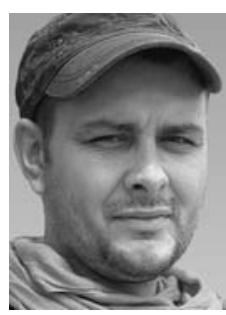

R. Sikora

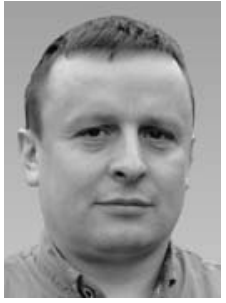

T. Wojciechowski

Landslides in the Sudetes. Prz. Geol., 67: 360-368; doi: 10.7306/2019.30

A b s tract. This paper presents the results of analysis of landslides distribution in the Sudetes (SW Poland). Our study was based on the analysis of the LiDAR-data digital elevation model and integrated with investigations of different factors for landslide development. The results of the study showed relationships between the spatial distribution of landslides and geology of their basement. For the areas built by Permo-Mesozoic and late Variscan sedimentary and volcanogenic rocks, the tectonic and lithological factors are predominant for landslide occurrences. The largest landslides have a tectonic affinity and represent a frontal type of geometry. The relationships between geological conditions and mass movements were also confirmed by the constructed landslide susceptibility map of the Sudetes.

Keywords: mass movements, digital elevation model, landslide susceptibility map, SW Poland

Zagrożenia osuwiskowe w polskiej części Sudetów, pomimo że znajduje się tam duża liczba osuwisk, są relatywnie mniejsze niż w innych regionach Polski. Brak wielkoskalowych i spektakularnych strat materialnych spowodowanych przez ruchy masowe w Sudetach przekłada się na świadomość o ich istnieniu. Stosunkowo mniejsza wiedza o osuwiskach jest też spowodowana problemami z ich właściwym rozpoznaniem, głównie w strefach, gdzie współwystępują one z formami o genezie tektonicznej. Generalnie liczba problemów osuwiskowych w Sudetach wydaje się niedoszacowana. Dotychczasowe opracowania map geologicznych (Berg i in., 1910; Berg, 1925; Grocholski, 1971; Bossowski i in., 1994; Kozdrój, 1994; Oberc $\mathrm{i}$ in., 1996) oraz starsze publikacje naukowe (Oberc, 1957; Dumanowski, 1967; Pulinowa, Mazur, 1971; Pulinowa, 1972, 1989) uwzględniały występowanie głównie pojedynczych osuwisk. Wraz z rozwojem technologii fotogrametrycznych i teledetekcyjnych oraz metod analitycznych obserwowano wzrost zainteresowania badawczego osuwiskami w Sudetach. Zaczęły pojawiać się prace opisujące analizy morfologiczne pod kątem identyfikacji osuwisk (Czerwiński, Żórawek, 1999; Synowiec, 2003a; Migoń, 2010; Migoń i in., 2010, 2014a, b, c, 2015, 2016; Migoń, Kasprzak, 2011; Kasprzak, Traczyk, 2012; Różycka i in., 2015; Duszyński i in., 2016; Jancewicz, Migoń, 2017; Osika i in., 2018). Niestety tylko niektóre badania uwzględniły geologiczne uwarunkowania rozwoju osuwisk (Migoń i in., 2010, 2017; Parzóch i in., 2012; Gotowała i in., 2015; Duszyński i in., 2016; Kasprzak i in., 2016; Sikora i in., 2016a, b, 2017; Kowalski, 2017 a, b; Kowalski, Wojewoda, 2017; Jancewicz, Traczyk, 2017; Sikora, Piotrowski, 2017).

Wykonanie dla powiatów sudeckich map osuwisk i terenów zagrożonych ruchami masowymi (MOTZ) w ramach Systemu Osłony Przeciwosuwiskowej (SOPO; Marciniec $\mathrm{i}$ in., 2019) jest planowane dopiero na późniejszym etapie projektu. Związane jest to $\mathrm{z}$ mniejszymi zagrożeniami, jakie niosą za sobą osuwiska w Sudetach, w porównaniu $\mathrm{z}$ innymi regionami Polski. Niemniej jednak, wstępna cha- rakterystyka problemów ruchów masowych w Sudetach, w skali regionalnej, wydaje się konieczna choćby do zaplanowania harmonogramu kompleksowych prac inwentaryzacyjnych osuwisk oraz określenia warunków, głównie geologicznych, w jakich one powstały. Kompleksowe analizy występowania osuwisk w Sudetach w odniesieniu do różnych czynników środowiskowych zostały wykonane tylko dla mezoregionu Gór Bardzkich (Sikora i in., 2017) i Gór Kamiennych (m.in.: Kasprzak, Traczyk, 2012). Badania o węższym zakresie przeprowadzono również dla Gór Stołowych (Migoń, Kasprzak, 2011, 2016; Duszyński i in., 2017) i NE obrzeżenia Gór Bystrzyckich (Różycka $\mathrm{i}$ in., 2015).

Niniejszy artykuł jest próbą charakterystyki Sudetów pod kątem ruchów masowych. Uzyskane wyniki mogą wypełniać lukę w wiedzy o rozmieszczeniu i liczbie osuwisk w Sudetach, ich charakterystyki i powiązaniu z budową geologiczna.

\section{METODYKA BADAŃ}

W badaniach przyjęto zasięg Sudetów zgodnie z regionalizacją fizycznogeograficzną Polski opracowaną przez Solana i in. (2018), w obszarze ograniczonym do makroregionów: Pogórze Zachodniosudeckie, Sudety Zachodnie, Sudety Środkowe oraz Sudety Wschodnie (ryc. 1). Dla tak zdefiniowanego terenu przeprowadzono szczegółową analizę w skali $1: 5000$ numerycznych modeli powierzchni terenu (NMPT), w celu określenia potencjalnych miejsc objętych osuwiskami. NMPT powstał na bazie danych uzyskanych w trakcie lotniczego skaningu laserowego, które pochodzą z Państwowego Zasobu Geodezyjnego i Kartograficznego (PZGiK). Zasięgi obszarów osuwiskowych wyznaczano z wykorzystaniem spersonalizowanych parametrów podświetlenia modelu terenu, w skali szarości, przy zmiennych kierunkach iluminacji. Kierunek iluminacji był uzależniony od układu grzbietów górskich i dolin rzecznych. W analizie wykorzystano również mapy topograficzne w skali $1: 10000 \mathrm{i}$ ortofotomapę.

${ }^{1}$ Państwowy Instytut Geologiczny - Państwowy Instytut Badawczy, Centrum Geozagrożeń, Skrzatów 1, 31-560 Kraków; rafal.sikora@pgi.gov.pl; tomasz.wojciechowski@pgi.gov.pl 


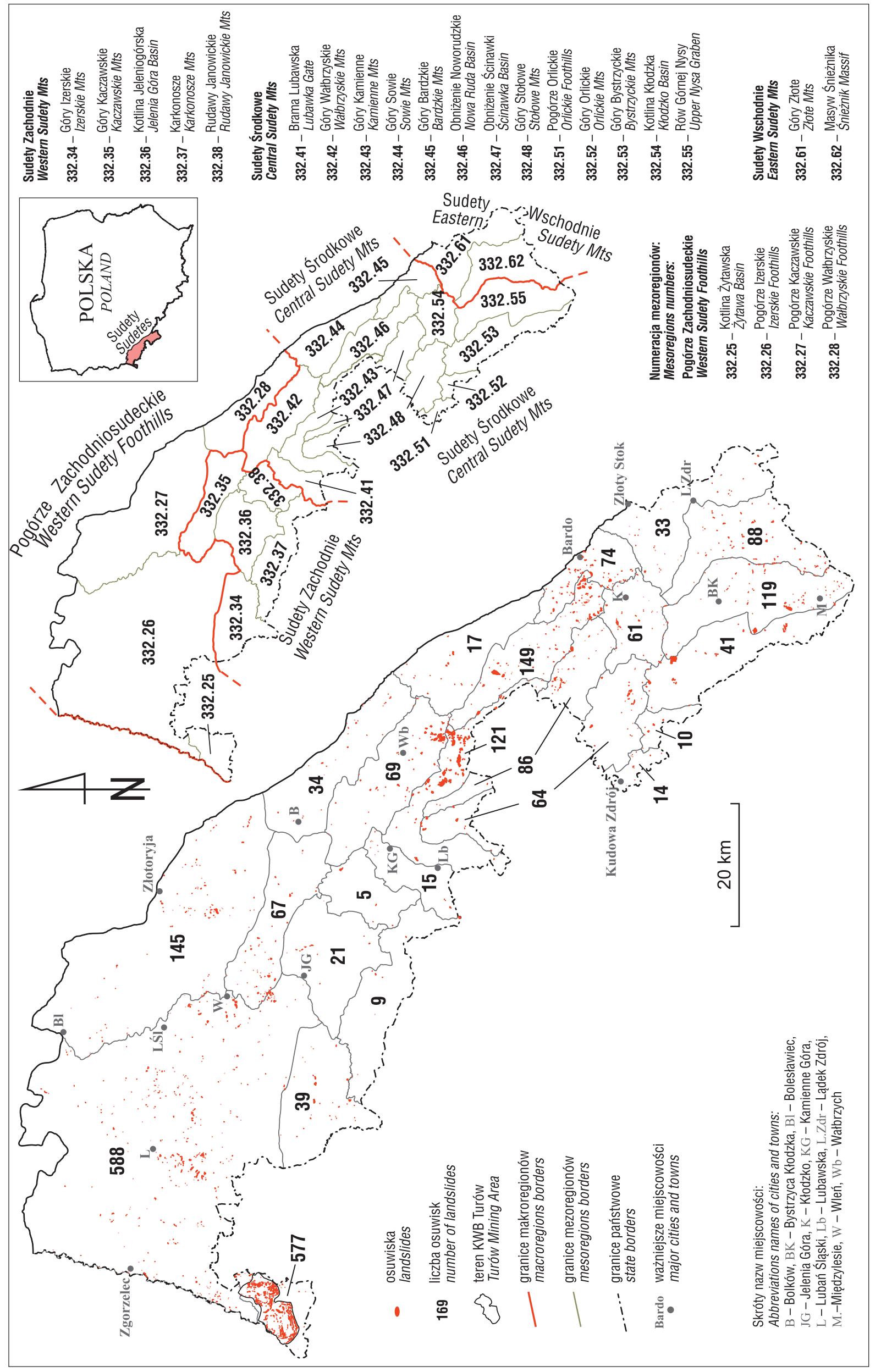


Podczas wyznaczania form osuwiskowych na poszczególnych obrazach NMPT zwracano uwagę m.in. na urozmaiconą rzeźbę powierzchni osuwisk. W wielu przypadkach, szczególnie przy dużych osuwiskach, bardzo wyraźnie zaznaczają się formy wewnętrzne, takie jak: skarpy główne i wtórne, rowy rozpadlinowe oraz progi akumulacyjne. Osuwiska w Sudetach często łączą się, tworząc kompleksy osuwiskowe, gdzie wyróżnienie poszczególnych, nasuwających się na siebie jęzorów jest bardzo utrudnione. Za zespoły osuwiskowe uznano również ciągi sąsiadujących ze sobą, stosunkowo niewielkich osuwisk rozwiniętych w ścianach wyrobisk górniczych oraz hałd i zwałowisk. Wiele małych form o niewyraźnie zaznaczającej się na NMPT morfologii klasyfikowano jako obszary potencjalnie osuwiskowe. Ze względu na dokładność danych wysokościowych i przyjętą skalę badań niemożliwe okazało się wyznaczenie wielu małych form typu spływów gruzłowych, błotnych lub kombinacji obu rodzajów. Problem ten dotyczy szczególnie polskiej części Karkonoszy, gdzie do tej pory zidentyfikowano ponad 70 form tego rodzaju (Migoń, Parzóch 2008; Parzóch, Migoń, 2010). Bazując na doświadczeniach $z$ innych regionów Polski, z bardzo dużym prawdopodobieństwem należy stwierdzić, że nie wyznaczono również bardzo wielu osuwisk, których skutki nie przejawiają się w rzeźbie terenu wizualizowanej z NMPT.

W celu obliczenia podatności osuwiskowej Sudetów określono tzw. czynniki bierne, czyli cechy środowiskowe, których wzajemne współwystępowanie może definiować stabilność stoków i zboczy. Informacje o litostratygrafii i tektonice obszaru badań pozyskano z map geologicznych (Sawicki, 1995; Cymerman, 2004). Na podstawie NMPT obliczono spadki, szorstkość oraz ekspozycję stoków, a także wysokość wyrażoną w m n.p.m. Do obliczeń wykorzystano ponadto informacje o pokryciu terenu, których źródłem jest baza danych obiektów ogólnogeograficznych (BDOO) należąca do zasobu PZGiK, oraz dane o odległości od cieków i zbiorników wodnych obliczone na podstawie Mapy Podziatu Hydrograficznego Polski w skali 1 : 10 000. Do obliczenia podatności osuwiskowej zastosowano statystyczną metodę wag przesłanek (WoE - Weights of Evidence; Bonham-Carter i in., 1989; Mrozek, 2013; Wojciechowski, 2019). Przy użyciu oprogramowania Global Mapper oraz ILWIS obszary osuwiskowe oraz podatność osuwiskową porównywano z zasięgami geologicznych jednostek strukturalnych i mezoregionów, które wynikają z regionalizacji tektonicznej (ryc. 4) i fizycznogeograficznej (ryc. 1).

\section{ROZMIESZCZENIE OSUWISK W SUDETACH}

W wyniku analizy NMPT wyznaczono 2444 osuwiska lub zespoły osuwiskowe (ryc. 1), a ich występowanie i rozmieszczenie skonfrontowano $\mathrm{z}$ danymi zawartymi w innych publikacjach. Należy zaznaczyć, że wg wcześniejszych zestawień liczba osuwisk w Sudetach była szacowana na 141 (Bażyński, Kuhn, 1971), 24 (Lemberger, 2005) lub 173 (Grabowski i in., 2008). Zidentyfikowane formy są zróżnicowane i wiele $\mathrm{z}$ nich tworzy zespoły osuwiskowe. Pod względem wielkości osuwisk dominują osuwiska bardzo małe o powierzchni poniżej 1ha (ryc. 2). Do tej klasy zakwalifikowano 2033 formy, co stanowi w przybliżeniu $83 \%$ wszystkich wyznaczonych osuwisk. W pozostałych klasach: 1-5 ha, 5-10 ha i powyżej 10 ha, ilość osuwisk jest znacznie mniejsza i stanowi ona odpowiednio 12,4\%, 2,9\% i 1,5\% form (ryc. 2). W Sudetach występują osuwiska skal-

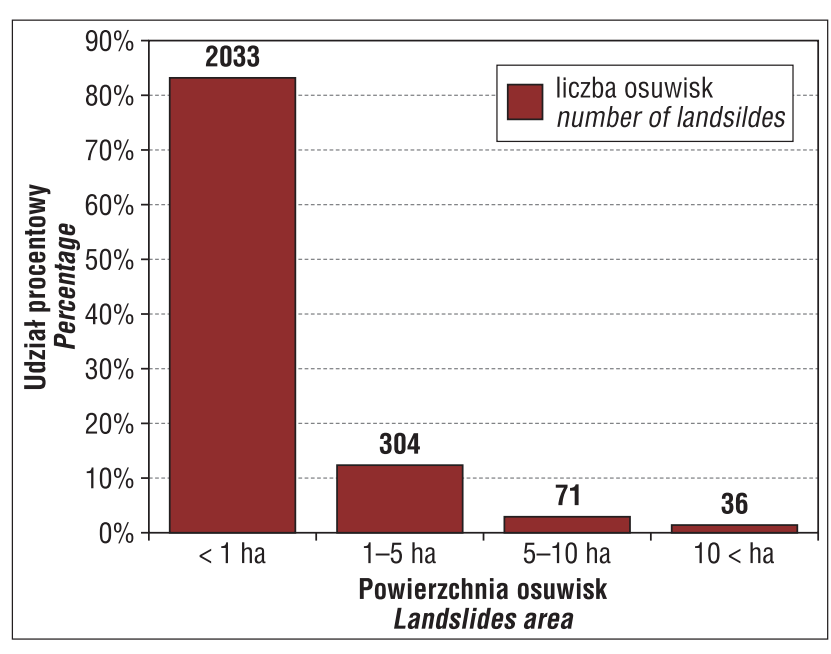

Ryc. 2. Rozkład wielkości osuwisk w Sudetach

Fig. 2. Landslide size distribution in the Sudetes

ne, zwietrzelinowe i skalno-zwietrzelinowe. Na tym obszarze mamy do czynienia ze zsuwami zarówno translacyjnymi, rotacyjnymi, jak i złożonymi. Oprócz osuwisk występują też inne typy ruchów masowych (m.in. spływy gruzłowo-błotne, obrywy skalne).

Rozmieszczenie przestrzenne osuwisk ukazuje duże zróżnicowanie regionalne w Sudetach. Ilość osuwisk w poszczególnych mezoregionach waha się od 3 do nawet 588 (ryc. 2). Największą liczbą wyznaczonych osuwisk cechują się następujące mezoregiony: Pogórze Izerskie 588 obszary osuwiskowe, Kotlina Żytawska - 577, Obniżenie Noworudzkie - 149, Góry Kamienne - 121, Rów Górnej Nysy Kłodzkiej - 119 oraz w Masywie Śnieżnika - 88 i Góry Bardzkie - 74.

Najwyższym wskaźnikiem osuwiskowości powierzchniowej (Bober, 1984), który procentowo wyraża stosunek powierzchni osuwisk do całej powierzchni definiowanej jednostki, charakteryzuje się Kotlina Żytawska (5,81\%), a następnie Góry Kamienne (2,48\%), Obniżenie Noworudzkie $(1,23 \%)$, Góry Bystrzyckie $(0,84 \%)$ i Góry Bardzkie $(0,81 \%)$.

Charakterystyczna pod względem osuwiskowości jest Kotlina Żytawska. Jest to szczególny region, ponieważ spośród 577 wyznaczonych tam osuwisk aż 95\% rozwinęło się na ścianach wyrobiska KWB „Turów” oraz zwałowisku zewnętrznym. Charakterystyczne na tym obszarze jest duże nagromadzenie osuwisk układających się w ciagi zlokalizowane wzdłuż ścian eksploatacyjnych (ryc. 1). Mimo że $97 \%$ osuwisk to formy bardzo małe i małe (do 5 ha powierzchni, ryc. 2), to na hałdzie na wschód od Bogatyni znajdują się rozległe formy osuwiskowe o powierzchniach przekraczających niekiedy 26 i 33 ha. Osuwiska w wyrobisku i na zboczach zwałowiska zewnętrznego KWB „Turów” są formami pochodzenia antropogenicznego i są wywołane odkrywkową eksploatacją pokładów węgla brunatnego lub składowaniem skały płonnej (Miłkowski i in., 2008; Szwarnowski, Kaczarewski, 2008).

Duża liczba osuwisk została wyznaczona na terenie Pogórza Izerskiego (588 form). W tym regionie również dominują bardzo małe i małe osuwiska (83\%). Ogółem osuwiska na tym obszarze zajmują $2,44 \mathrm{~km}^{2}$, co stanowi tylko $0,15 \%$ jego powierzchni (ryc. 3 ). Najwięcej osuwisk na Pogórzu Izerskim zidentyfikowano w dolinie Kwisy, pomiędzy Leśną a Lubaniem. Znajdują się tam również największe w tym regionie osuwiska, osiągające powierzchnie 


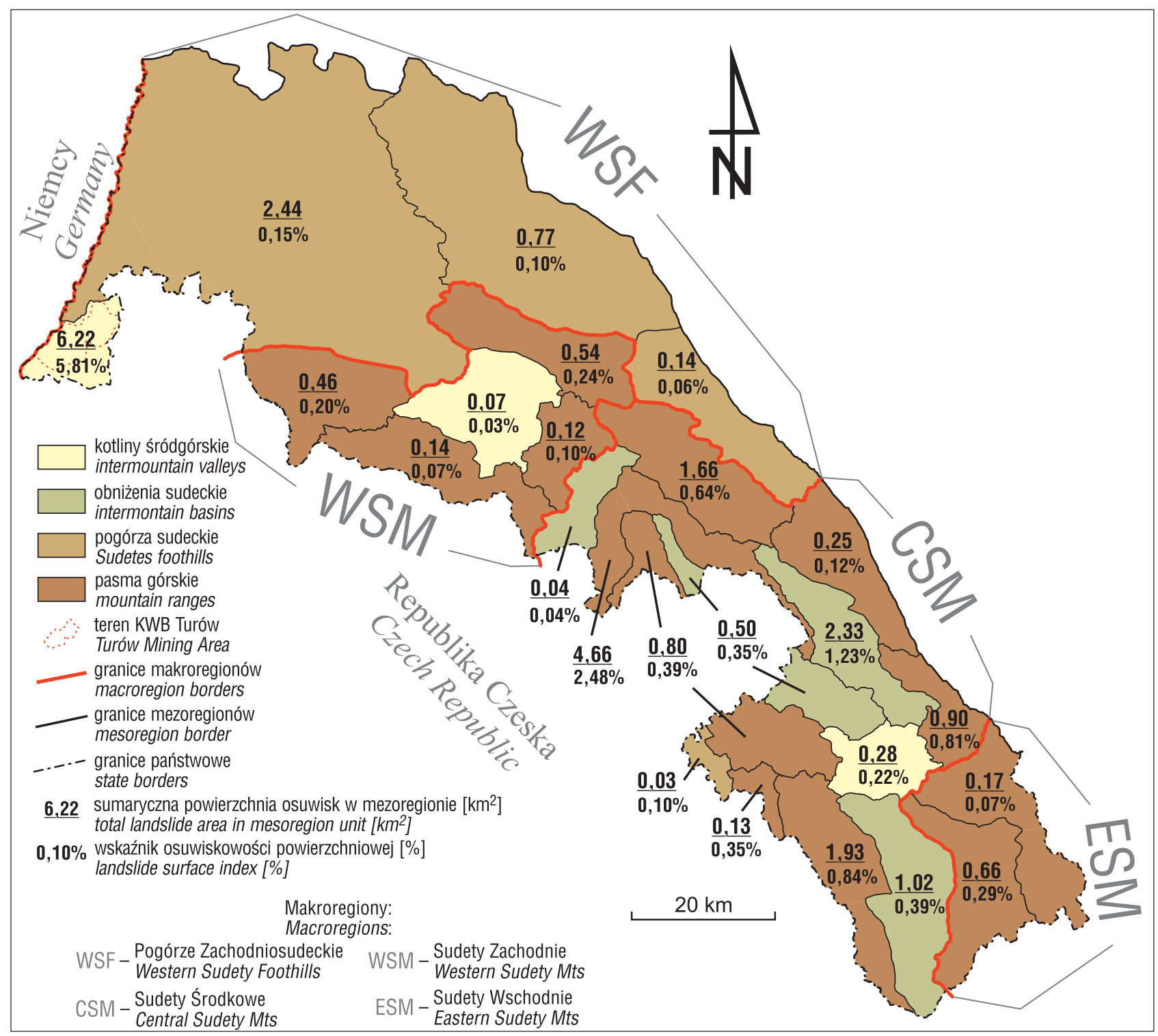

Ryc. 3. Sumaryczna powierzchnia osuwisk oraz wskaźnik osuwiskowości powierzchniowej w poszczególnych mezoregionach Sudeckich Fig. 3. Total landslide area and landslide surface index for the Sudetes mesoregions

od 4 do 6 ha. Są to formy typu frontalnego (Ziętara, 1968; Pulinowa, 1972), nawiązujące do układu morfologicznego grzbietów i dolin w kierunku WNW- ESE, który jest poprzeczny do południkowo przebiegającej doliny Kwisy.

Duże nagromadzenie osuwisk jest obserwowane również na pograniczu Pogórza Izerskiego i Gór Kaczawskich. W dolinie Bobru, na południe od Wlenia, rozpoznano 12 form, a na wschód od Jeziora Pilchowickiego - 47 (ryc. 1), które znajdują się głównie między Siedlęcinem a Pilchowicami (Sikora i in., 2016a; Kowalski, 2017a). W pierwszym rejonie osuwiska rozwinęły się głównie na SW stokach grzbietów o przebiegu WNW-ESE, czyli poprzecznych do doliny Bobru. Są to głównie osuwiska o powierzchniach od 1,10 do 5,72 ha (ryc. 2). W drugim rejonie układ grzbietów, na których wykształciły się osuwiska, jest w przybliżeniu równoległy do doliny Bobru, przybierającej tu kierunek NW-SE. Największe osuwiska mają powierzchnie 1,54,5 ha, a ok. $2 \mathrm{~km}$ na wschód od opisywanego rejonu w dolinie Płoszczynki znajduje się osuwisko osiagające 9,28 ha.

$\mathrm{Na}$ Pogórzu Kaczawskim znajduje się 145 osuwisk o łącznej powierzchni $0,77 \mathrm{~km}^{2}$, co stanowi $0,10 \%$ obszaru regionu. Najwięcej osuwisk zlokalizowano w dolinie Kaczawy, szczególnie między Sędziszową a Nowym Kościołem (28 form), oraz w dolinie Bystrzyka, na NW od Kondratowa (13 form). Powierzchnie większości osuwisk w opisywanej centralnej części Pogórza Kaczawskiego nie przekraczają 1,2 ha. Wyjątkiem jest zespół osuwisk typu frontalnego na $\mathrm{N}$ stoku Wielisławki (376,3 m n.p.m.) o powierzchni 21,46 ha i osuwiska na E stoku Góry Wołek (381,07 m n.p.m.) o powierzchni 3,17 ha (Kowalski, Wojewoda, 2017).

Rejon obejmujący północno-wschodnią cześć Gór Kamiennych (Góry Suche i Pasmo Lesistej) oraz południową Gór Wałbrzyskich (Grzbiet Rybnicki) jest drugim najwyraźniej zaznaczającym się obszarem o wysokim zagęszczeniu osuwisk w Sudetach. Znajduje się tam większość spośród 122 osuwisk wyznaczonych w Górach Kamiennych oraz z 69 osuwisk rozpoznanych w Górach Wałbrzyskich. Charakteryzują się one dużą złożonością, mnogim występowaniem wyraźnych form wewnątrzosuwiskowych oraz głęboko usytuowanymi płaszczyznami poślizgu (por. Synowiec, 2003b; Migoń i in., 2014b; Kasprzak i in., 2016). Kilkanaście $\mathrm{z}$ nich przekracza powierzchnię 10 ha. W Górach 
Kamiennych występują one w Paśmie Dzikowca, na NE stokach Lesistej Wielkiej (851 m n.p.m.), N stoku Stożka Wielkiego (841 m n.p.m.) i Turzyny (895 m n.p.m.), E sto ku Rogowca (870 m n.p.m.) oraz na stokach Jeleńca Małego (760 m n.p.m.). Największy zespół osuwiskowy rozwinął się na $\mathrm{N}$ stoku grzbietu Włostowa-KostrzynaSuchawka i zajmuje powierzchnię 62,60 ha, czyli nieco większą niż podali Kasprzak i Traczyk (2012). Na stokach Rybnickiego Grzbietu w Górach Wałbrzyskich największe z osuwisk osiąga powierzchnię 18,75 ha. Większość wymienionych form można określić jako osuwiska frontalne, których rozmieszczenie oraz układ skarp i rowów rozpadlinowych nawiązują do przebiegu dolin i grzbietów górskich z NW ku E charakterystycznego dla północnej części Gór Kamiennych i Gór Wałbrzyskich.

Obszar południowo-wschodniej części Obniżenia Noworudzkiego wg tradycyjnego podziału fizycznogeograficznego (Kondracki, 2002) należał do Gór Bardzkich. $\mathrm{W}$ takim ujęciu w tym rejonie wykazano istnienie ponad 100 osuwisk (Sikora i in., 2017; Sikora i Piotrowski, 2017). Są to różnej wielkości formy z reguły nieprzekraczające wielkości 10 ha i zlokalizowane głównie w przełomowej dolinie Nysy Kłodzkiej oraz w jej bezpośrednim sąsiedztwie, a także na SW stokach Garbu Golińca schodzących do doliny Ścinawki. Największe osuwisko w tym rejonie (ok. 16 ha), które schodzi do koryta Nysy Kłodzkiej Podtyniem a Bardem (N stok Góry Nyskiej, 426,8 m n.p.m.), reprezentuje typ frontalny.

Kolejny wyróżniający się rejon na mapie osuwiskowości Sudetów obejmuje południowe obrzeżenie Gór Stołowych oraz północno-wschodnie stoki Gór Bystrzyckich (w sumie 50 osuwisk; ryc. 1). Wśród 29 osuwisk na obrzeżeniu Gór Stołowych wyróżniają się duże frontalne formy (od 1,9 do 6,48 ha) rozwinięte na SW stoku Góry Hanuli (846,8 m n.p.m.) oraz mniejsze osuwiska (do 0,6 ha) w dolinie Kamiennego Potoku, na zachód od Szczytnej (por. Duszyński i in., 2017). Rozkład osuwisk w tej części opisywanego rejonu nawiązuje do kierunku WNW-ESE, jaki wyznacza krawędź morfologiczna Gór Stołowych, i kierunku W-E doliny Kamiennego Potoku. Większe formy i zespoły osuwiskowe zaznaczają się w Górach Bystrzyckich. Wyróżnić tu należy osuwisko rozwinięte na $\mathrm{N}$ stoku Góry Złotej (637 m n.p.m) o powierzchni 15 ha, zespół 5 osuwisk zlokalizowany na NE stoku Toczka (710 m n.p.m.) o łącznej powierzchni 120,60 ha (por. Różycka i in., 2015, 2016; Migoń i in., 2015; Sikora i in., 2016b) oraz położone kilkaset metrów na południe bardzo duże osuwisko o powierzchni 42,87 ha. Zarówno zespół osuwiskowy Toczka, jak i ostatnia z wymienionych form wykształciły się na wyraźnym progu morfologicznym o kierunku NW-SE, który oddziela Góry Bystrzyckie od Rowu Górnej Nysy Kłodzkiej. Osuwisko na Górze Złotej (639,5 m n.p.m.) i największe spośród osuwisk na Toczku (710 m n.p.m.) reprezentują typ osuwisk frontalnych. Do form frontalnych należy także zaliczać zespół osuwisk na NE stoku Szczelińca Wielkiego (919 m n.p.m.; por. Migoń, Kasprzak, 2011; Duszyński i in., 2017).

W południowej części Sudetów nagromadzenia osuwisk występują na pograniczu Rowu Górnej Nysy Kłodzkiej z Górami Bystrzyckimi i Masywem Śnieżnika. W okolicy Gniewoszowa i Różanki znajduje się ich ponad 30, głównie małych i średnich. Wśród nich wyróżnia się rozległe osuwisko na wschodnim stoku Jagodnej (977 m n.p.m.), które zajmuje powierzchnię 31,79 ha, więc większą niż wyznaczyli Różycka i in. (2015). Układ i rozmieszczenie tych osuwisk są związane z występowaniem progu morfologicznego oddzielającego Góry Bystrzyckie od Rowu Górnej Nysy Kłodzkiej, który przebiega w kierunku południkowym. Na przebiegającej południkowo krawędzi Masywu Śnieżnika i Rowu Górnej Nysy Kłodzkiej rozciaga się wiele ok. 70 bardzo małych i małych osuwisk o powierzchniach poniżej 2,5 ha.

\section{ZWIĄZEK OSUWISK Z GEOLOGIĄ SUDETÓW}

Budowa geologiczna Sudetów ma znaczny wpływ na ich rzeźbę terenu (Placek, 2011; Migoń, Placek, 2014) tym samym może warunkować rozmieszczenie i układ osuwisk. W rejonie Pogórza Izerskiego, Gór Kaczawskich, Gór Stołowych, Obniżenia Noworudzkiego, Gór Bardzkich oraz w dużej mierze w Górach Kamiennych i Górach Wałbrzyskich rozkład wielu osuwisk i układ podłużnych elementów ich rzeźby (skarp, rowów rozpadlinowych, czół) nawiązuje do typowego dla znacznej części Sudetów WNW-ESE do NW-SE kierunku rozciąłłości struktur geologicznych. W tym kierunku rozciągają się najważniejsze strefy uskokowe, które często zaznaczają się w morfologii terenu. Analiza rozmieszczenia osuwisk na tle budowy geologicznej Sudetów (ryc. 4) sugeruje ścisłe zależności między ich rozwojem a geologią podłoża. Związki osuwisk z uskokami, strefami kataklazy i spękaniami w podłożu wskazali Sikora i in. (2016a) oraz Kowalski (2017a) w dolinie Bobru (uskok śródsudecki, uskok południowy rowu Wlenia), Sikora i in. (2016b) oraz Sikora i Piotrowski (2017) w Górach Bardzkich, a także Duszyński i inni (2016), Kasprzak i in. (2016) oraz Migoń i in. (2017) w Górach Kamiennych.

Mimo że wiele osuwisk rozwinęło się w utworach czwartorzędowych (m.in. między Leśną a Lubaniem i na wschód od Jeziora Pilchowickiego), kierunki skarp osuwiskowych są zgodne z przebiegiem głębszych struktur geologicznych. W Górach Bardzkich i w południowej części Obniżenia Noworudzkiego utwory czwartorzędowe na znacznej przestrzeni stanowią pokrywę skał paleozoicznych. Prace terenowe oraz analizy strukturalne spękań i uskoków (Sikora i in., 2016b; Sikora, Piotrowski, 2017) wykazały jednak, że w tej części Sudetów odkucie mas skalnych większych osuwisk zachodzi w skałach karbońskich i jest warunkowane strukturami tektonicznymi. Dotyczy to głównie struktur równoległych (NW-SE) lub skośnych (WNW-ESE) do uskoku sudeckiego brzeżnego oraz nasunięcia kłodzkiego. Na rozwój osuwisk na obszarach objętych procesami tektonicznymi mogą oddziaływać czynniki neotektoniczne (Badura i in., 2007) i klimatyczne (Żurawek 1999). Południkowo przebiegające krawędzie morfologiczne, które ograniczają centralną i południową część Rowu Górnej Nysy Kłodzkiej, mają założenia uskokowe. O wpływie tych dyslokacji na rozwój osuwisk napisali m.in. Gotowała i in. (2015), Różycka i in. (2015), Sikora i in. (2016b) oraz Wojewoda, Kowalski (2016).

Obok czynnika tektonicznego w rozmieszczeniu i rozwoju osuwisk w Sudetach istotną rolę odgrywa litologia podłoża. Porównanie rozmieszczenia przestrzennego osuwisk z podziałem tektonicznym Sudetów (ryc. 4) wskazuje, że największa liczba osuwisk znajduje się w obszarach, w których podłoże skalne stanowią skały osadowe.

Osuwiska w zachodniej części Pogórza Zachodniosudeckiego wykształciły się głównie w utworach czwartorzędowych i neogeńskich (ryc. 4). We wschodniej części Pogórza Izerskiego, w Górach Kaczawskich i na Pogórzu 


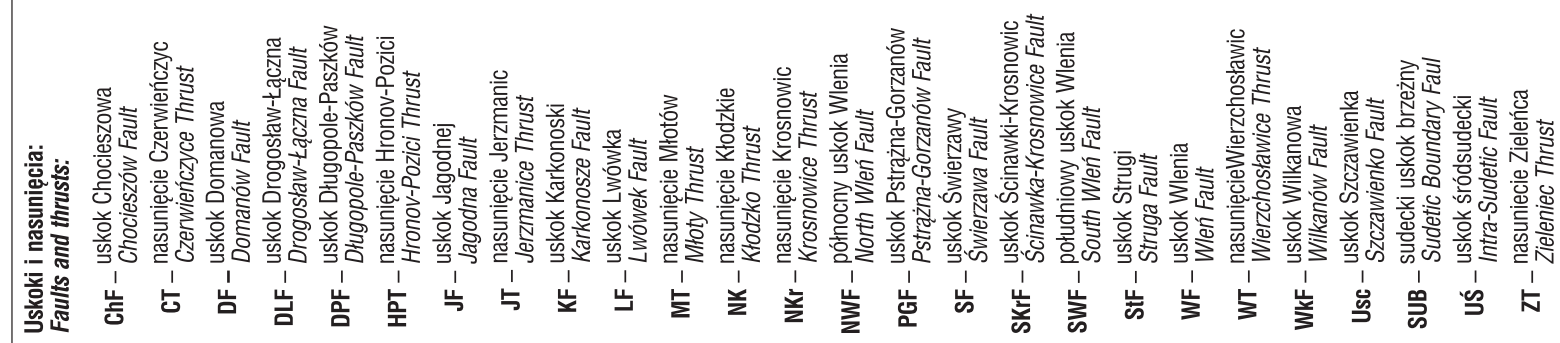

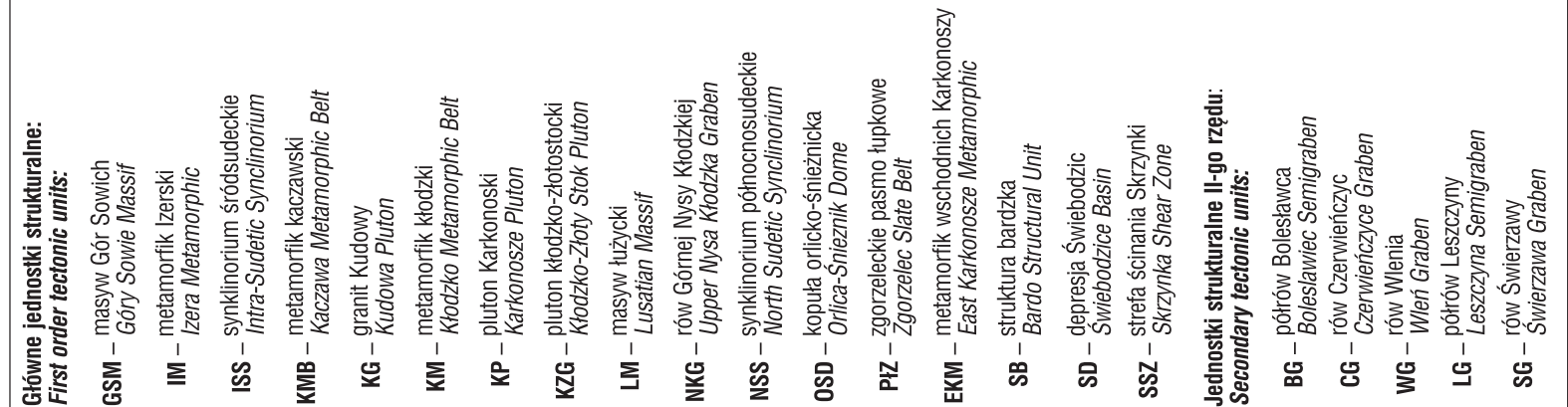

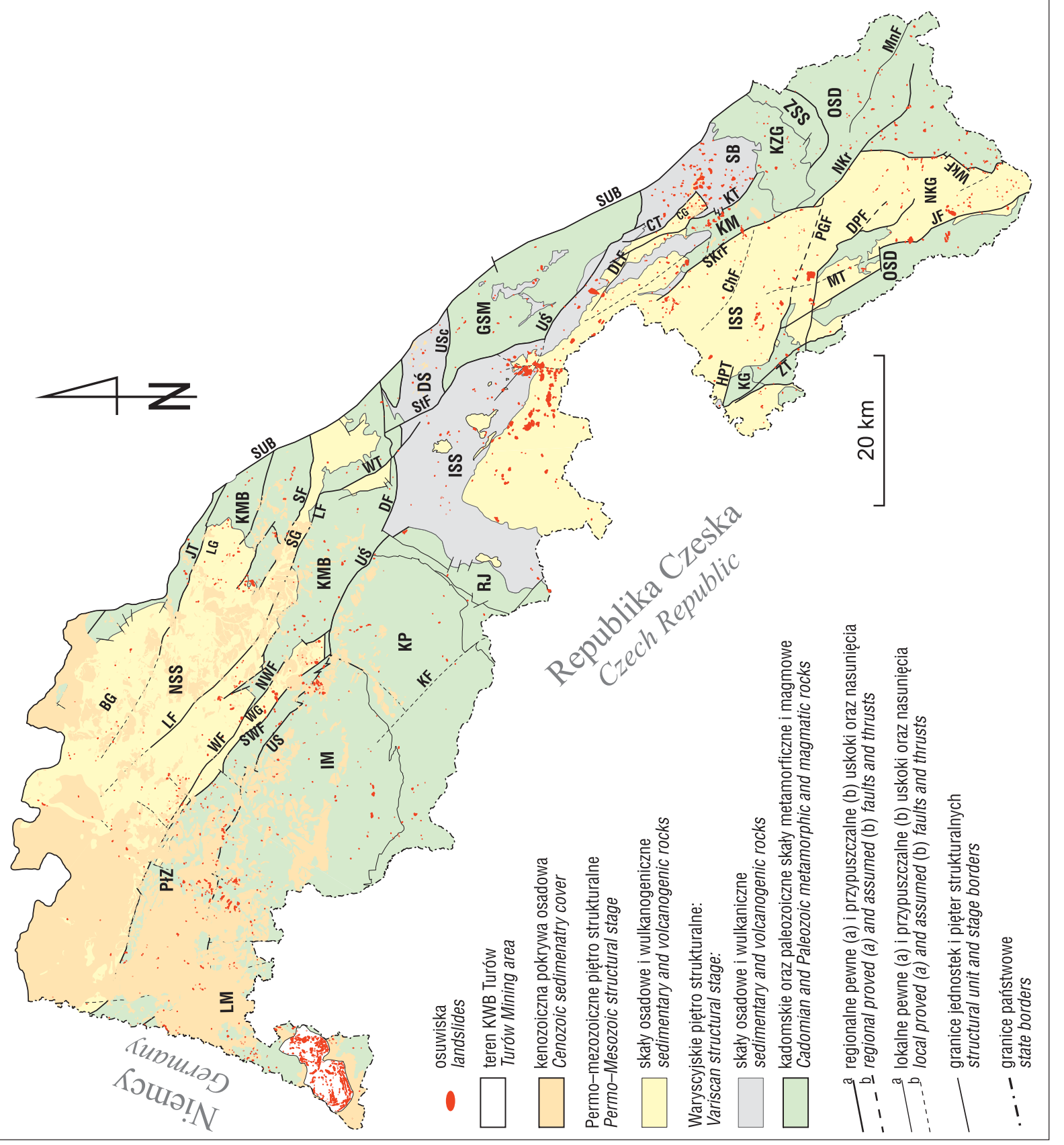

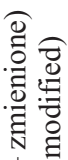
응응 ఏ. 空 过过 हี 톄 ๙ूँ 鈨 解 这离

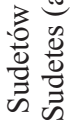
品异 要 


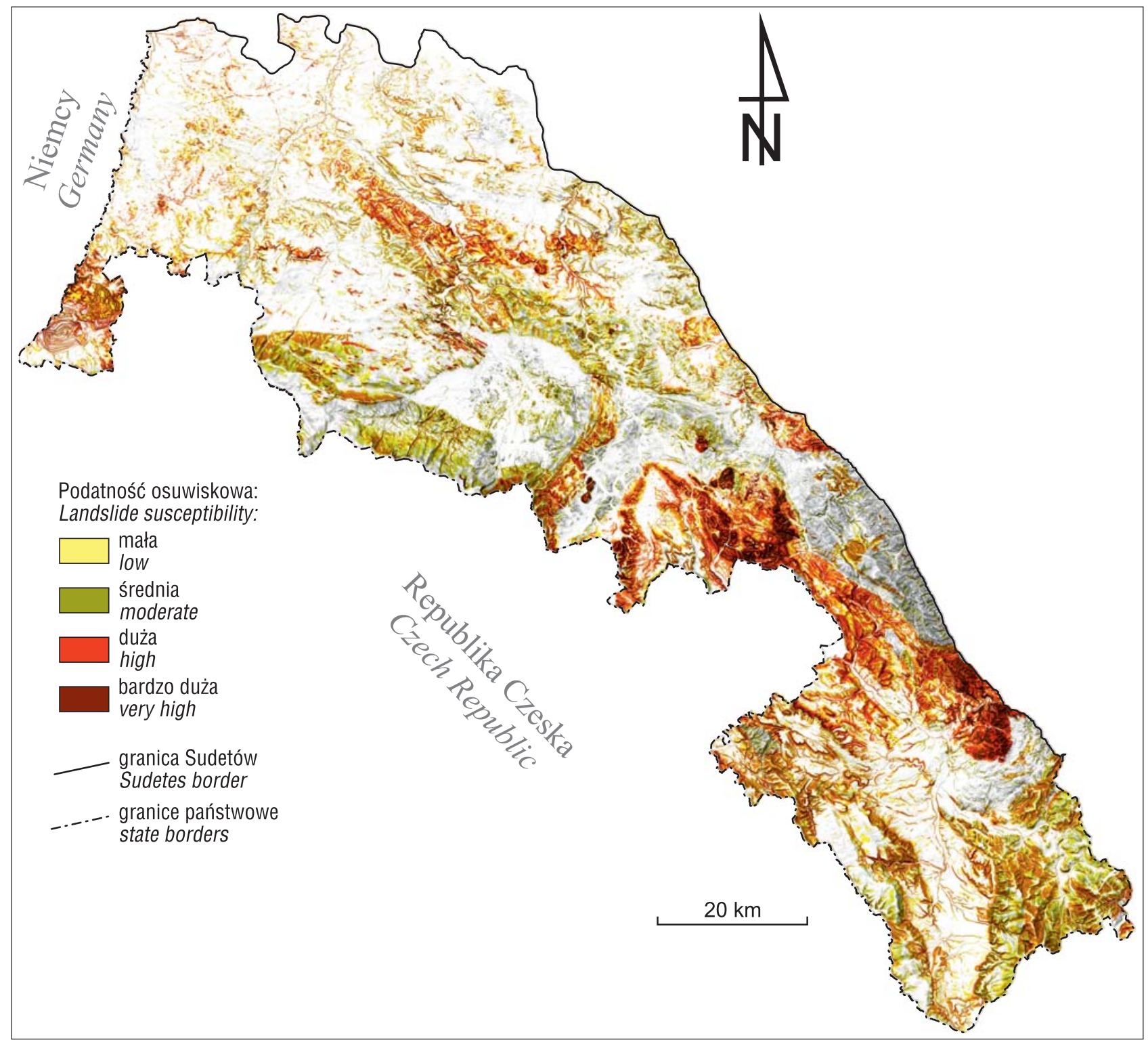

Ryc. 5. Mapa podatności osuwiskowej Sudetów

Fig. 5. Landslide susceptibility map of the Sudetes

Kaczawskim osuwiska rozwinęły się przede wszystkim w permsko-mezozoicznych utworach synklinorium północnosudeckiego i będących jego przedłużeniem rowach tektonicznych Wlenia, Świerzawy oraz półrowie Leszczyny. Część osuwisk na tym obszarze jest związana z wulkanogenicznymi intruzjami w obrębie skał metamorficznych (Kowalski, Wojewoda, 2017), a niekiedy ze skałami niskiego stopnia metamorfizmu, które budują metamorficzny kompleks kaczawski (Sikora i in., 2016a).

Jednostką strukturalną, w której wykształciło się zdecydowanie najwięcej osuwisk jest synklinorium śródsudeckie (ryc. 4). Najliczniej występują one na stokach Gór Kamiennych i Gór Wałbrzyskich, zbudowanych z permskich skał wulkanogenicznych i klastycznych. Osuwiskami objęte są również stoki zbudowane z permskich i karbońskich skał klastycznych i wulkanicznych w obrębie rowu Czerwieńczyc. Ruchy masowe powstawały także w obrębie klastycznych utworów górnej kredy w Górach Stołowych oraz na pograniczu Rowu Górnej Nysy Kłodzkiej z Górami Bystrzyckimi i Masywem Śnieżnika.

Większość osuwisk rozpoznanych w Górach Bardzkich jest związana z obszarem, którego podłoże stanowią silnie zdeformowane dolnokarbońskie klastyczne skały struktury bardzkiej (ryc. 4). Na terenach o podłożu zbudowanym ze skał plutonicznych (różnych odmian granitoidów, gabr) oraz średniego i wysokiego stopnia metamorfizmu (m.in.: gnejsy, granitognejsy, amfibolity) występują bardzo małe i małe osuwiska. Dotyczy to masywów łużyckiego, karkonosko-izerskiego, Gór Sowich, plutonu kłodzko-złotostockiego i kopuły orlicko-śnieżnickiej. Na stokach o takim podłożu ruchy masowe zachodzą głównie w postaci spływów gruzłowo-błotnych lub zsuwów pokryw zwietrzelinowych (Żurawek, 1999; Parzóch, Migoń, 2010; Parzóch i in., 2012; Makoś, Sobczyk, 2018).

\section{PODATNOŚĆ OSUWISKOWA SUDETÓW}

Do obliczenia podatności osuwiskowej Sudetów wzięto pod uwagę litologię, tektonikę (uskoki i nasunięcia), spadki terenu, wskaźnik szorstkości powierzchni terenu, ekspozycję stoków, wysokość n.p.m., pokrycie terenu oraz odległość od cieków i zbiorników wodnych. Podstawą obliczenia podatności osuwiskowej dla każdego obszaru jest sprawdzenie, czy przyjęte czynniki bierne są niezależ- 
ne od siebie (Mrozek, 2013). W przypadku opisywanych badań silną korelacją z innymi czynnikami charakteryzowały się: szorstkość powierzchni terenu, wysokość n.p.m oraz pokrycie terenu, dlatego też zostały one pomięte w dalszych analizach. Mapa podatności osuwiskowej Sudetów (ryc. 5) została sklasyfikowana na 5 przedziałów: od małej podatności osuwiskowej do bardzo dużej.Wynika z niej, że $62 \%$ obszaru badań wydaje się nieistotna pod względem osuwiskowym. Bardzo dużą i dużą podatnością charakteryzuje się blisko 8\% polskiej części Sudetów.

Zdecydowanie największą podatność na ruchy osuwiskowe mają Góry Kamienne i Góry Bardzkie (ryc. 5). W dalszej kolejności dużym prawdopodobieństwem wystąpienia osuwisk charakteryzują sie południowe części Gór Wałbrzyskich, Obniżenie Noworudzkie, środkowa część Pogórza Wałbrzyskiego i Obniżenie Ścinawki. Największą podatnością osuwiskową charakteryzują się tereny zbudowane przede wszystkim z górnokarbońskich oraz dolnopermskich skał wulkanogenicznych i osadowych oraz dolnokarbońskich utworów fliszowych. Pod względem podatności osuwiskowej wyróżnia się także obszar Kotliny Żytawskiej wypełnionej osadami neogeńskimi. Ma to jednak związek $\mathrm{z}$ antropogenicznym przekształceniem terenu na obszarze KWB „Turów” w wyniku formowania stromych ścian wyrobisk oraz zwałowiska zewnętrznego.

Mapa podatności osuwiskowej Sudetów wskazuje miejsca bardziej, bądź mniej podatne na osunięcia w przyszłości. Podatność wzrasta z nachyleniem terenu, przy czym zaczyna być istotna już przy nachyleniu $9^{\circ}$. Osuwiska w Sudetach mogą częściej powstawać w bliskiej odległości do cieków wodnych oraz na stokach o ekspozycjach: S, SW, E.

\section{PODSUMOWANIE}

Sudety są drugim co do wielkości pasmem górskim w Polsce i regionem o znacznej na tle całego kraju podatności osuwiskowej (Wojciechowski, 2019). Wyniki badań wykazały istnienie w Sudetach głównie bardzo małych i małych osuwisk oraz ich nierównomierne rozmieszczenie przestrzenne. Ich rozmiary i liczba, a także bardzo niskie wartości wskaźników osuwiskowości powierzchniowej w poszczególnych mezoregionach - od 0,03\% w Kotlinie Jeleniogórskiej do 2,48\% w Górach Kamiennych, wskazują na znacznie mniejszą osuwiskowość tego regionu w stosunku do Karpat, gdzie wskaźniki osuwiskowości często przekraczają 20\% (Kaczorowski, Kułak, 2019). Najwyższy wskaźnik osuwiskowości powierzchniowej o wartości 5,51\% w Kotlinie Żytawskiej jest wywołany czynnikami antropogenicznymi. Biorąc pod uwagę uwarunkowania naturalne, obszarami najbardziej osuwiskowymi w Sudetach są Góry Kamienne, Góry Bardzkie, Obniżenie Noworudzkie, Góry Wałbrzyskie, niektóre rejony Rowu Górnej Nysy Kłodzkiej, Gór Kaczawskich oraz Pogórzy Izerskiego i Kaczawskiego. Potwierdziły to zarówno analizy rozmieszczenia osuwisk, jak i wyniki obliczeń podatności osuwiskowej Sudetów. Na rozwój i rozmieszczenie osuwisk mają wpływ głównie czynniki związane ze strukturą i litologią podłoża. Najwięcej osuwisk i największe z nich znajdują się w obrębie synklinorium śródsudeckiego i Rowu Górnej Nysy Kłodzkiej oraz synklinorium północnosudeckiego i będących jego przedłużeniem rowów tektonicznych Wlenia, Świerzawy i Leszczyny. Sa to przede wszystkim osuwiska występujące na skałach osadowych młodszego (permsko-mezozoicznego) piętra strukturalnego Sudetów.
Uwagę zwraca fakt, że na tych obszarach istotny udział w procesach osuwiskowych mają utwory wulkanogeniczne. Liczne osuwiska na obszarze struktury bardzkiej są związane z podłożem dolnokarbońskim (starsze, waryscyjskie piętro strukturalne) i jego pokrywą plejstoceńską. Pod względem osuwiskowości wyróżniają się obszary, na których występują utwory plejstoceńskie w zachodniej części Sudetów. Rozwojowi osuwisk w Sudetach sprzyja obecność wyraźnych progów morfologicznych związanych z tektoniką uskokową podłoża (m.in. Rów Górnej Nysy Kłodzkiej, Góry Bardzkie) lub spękaniami i różną odpornością skał (m.in. Góry Kamienne). W tych rejonach częste są osuwiska typu frontalnego.

Przedstawione w artykule badania opierają się głównie na analizie NMPT, który jest narzędziem pomocniczym w wyznaczaniu osuwisk i określaniu ich parametrów. Należy zaznaczyć, że w toku badań niemożliwe było rozpoznanie wielu bardzo małych form i osuwisk, np. typu spływów gruzłowo-błotnych i obrywów skalnych. Do ich identyfikacji są konieczne kartograficzne prace terenowe. Rzeczywista osuwiskowość Sudetów zostanie określona dopiero po wykonaniu Mapy osuwisk i terenów zagrożonych ruchami masowymi w skali 1 : 10000 na tym obszarze w ramach projektu SOPO.

\section{LITERATURA}

BAŻYŃSKI J., KÜHN A. 1971 - Rejestracja osuwisk w Polsce. Inst. Geol., Warszawa.

BERG G. 1925 - Geologische Karte von Preussen 1 : 25 000. Blatt Waldenburg.

BERG G., Dathe E., Zimmermann E. 1910 - Geologische Karte von Preussen $1: 25$ 000. Blatt Friedland i. Schl.

BOBER L. 1984 - Rejony osuwiskowe w polskich Karpatach fliszowych $\mathrm{i}$ ich związek z budową geologiczną regionu. Biul. Inst. Geol., 340: $115-158$.

BONHAM-CARTER G.F., AGTERBERG F.P., WRIGHT D.F. $1989-$ Weight of evidence modeling: a new approach to mapping mineral potential. Statistical Applications in the Earth Science. Geol. Surv. Can. Pap., 89 (9): 171-183.

BOSSOWSKI A., CYMERMAN Z., GROCHOLSKI A., IHNATOWICZ A. 1994 - Szczegółowa Mapa Geologiczna Sudetów w skali 1 : 25 000, ark. Jedlina Zdrój. Państw. Inst. Geol., Warszawa.

CYMERMAN Z. 2004 - Tectonic map of the Sudetes and the Fore-Sudetic Block. Państw. Inst. Geol., Warszawa.

CZERWIŃSKI J., ŻURAWEK R. 1999 - The geomorphological effects of heavy rain falls and flooding in the Polish Sudetes in July 1997. Stud. Geomorph. Carpat.-Balcan., 33: 27-43.

DUSZYŃSKI F., MIGOŃ P., RÓŻYCKA M. 2016 - Osuwisko pod Turzyną w Górach Suchych (Sudety Srodkowe). Przyr. Sud., 19: 143-166. DUSZYŃSKI F., JANCEWICZ K., KASPRZAK M., MIGOŃ P. $2017-$ The role of landslides in downslope transport of caprock-derived boulders in sedimentary tablelands, Stołowe Mts, SW Poland. Geomorph., 295: 84-101.

DUMANOWSKI B. 1961 - Zagadnienie rozwoju stoku na przykładzie Gór Stołowych. Czas. Geogr., 32: 311-324.

GOTOWAŁA R., KOWALSKI A., SOBCZYK A., WOJEWODA J. 2015 - Structurally-controlled landslide (Toczek Mt., Intrasudetic Shear Zone). [W: $16^{\text {th }}$ Czech-Polish Workshop on Recent Geodynamics of the Sudeten and Adjacent Areas. Abstracts. Srebrna Góra, Poland, November 5-7 2015, UPWr, Wrocław: 23.

GRABOWSKI D., MARCINIEC P., MROZEK T., NESCIERUK P., RACZKOWSKI W., WOJCIK A., ZIMNAL Z. 2008 - Instrukcja opracowania Mapy osuwisk i terenów zagrożonych ruchami masowymi w skali 1: 10000 . Min. Środ., Warszawa.

GROCHOLSKI A. 1971 - Szczegółowa Mapa Geologiczna Sudetów w skali 1 : 25 000, ark. Mieroszów. Wyd. Geol., Warszawa.

JANCEWICZ K., MIGOŃ P. 2017 - Osuwiska w Masywie Granicznika w Górach Kamiennych. Przyr. Sud., 20: 239-254.

JANCEWICZ K., TRACZYK A. 2017 - Mało znane formy ruchów masowych w dolinie Węglówki w Górach Bardzkich (Sudety Środkowe). Przyr. Sud. 20: 289-314.

KACZOROWSKI J., KUŁAK M., 2019 - Osuwiska w polskich Karpatach w ujęciu statystycznym na podstawie wyników Projektu SOPO. II Ogólnopolska Konferencja Osuwiskowa. 14-17 maja 2019. Materiały konferencyjne. 
KASPRZAK M., TRACZYK A. 2012 - Uwarunkowania rozwoju osuwisk w środkowej części Gór Kamiennych (Sudety). Land. Analysis, 20: 65-77.

KASPRZAK M., DUSZYŃSKI F., JANCEWICZ K., MICHNIEWICZ A., RÓŻYCKA M., MIGOŃ P. 2016 - The Rogowiec Landslide Complex (Central Sudetes, SW Poland) - a case of a collapsed mountain. Geol. Quart., 60 (3): 695-713.

KONDRACKI J. 2002 - Geografia regionalna Polski. PWN, Warszawa. KOWALSKI A. 2017a - Rozmieszczenie i geneza form osuwiskowych w przełomowej dolinie Bobru w okolicach Wlenia (Sudety Zachodnie) Prz. Geol., 65: 629-641.

KOWALSKI A. 2017b - Ruchy masowe a interpretacja budowy geologicznej - przykład osuwiska na górze Drogosz w paśmie Zaworów (Sudety Środkowe). Prz. Geol., 65: 96-104.

KOWALSKI A., WOJEWODA J. 2017 - Nowo rozpoznane formy osuwiskowe w dolinie Kaczawy na Pogórzu Kaczawskim (Sudety Zachodnie). Land. Analysis, 34: 15-27

KOZDRÓJ W. 1994 - Szczegółowa Mapa Geologiczna Sudetów w skali $1: 25000$, ark. Poręba. Państw. Inst. Geol., Warszawa.

LEMBERGER M. (red) 2005 - Rejestracja i inwentaryzacja naturalnych zagrożeń geologicznych na terenie całego kraju (ze szczególnym uwzględnieniem osuwisk oraz innych zjawisk geodynamicznych). AGH, Kraków: 23-83.

MAKOS M., SOBCZYK A. 2018 - Przydatność pomiarów georadarowych i analiz geomorfometrycznych do rozpoznania wewnętrznej struktury płytkich osuwisk - na przykładzie góry Średniak w Masywie Śnieżnika, Sudety Wschodnie. Prz. Geol., 66 (10): 636-647.

MARCINIEC P., ZIMNAL Z., WOJCIECHOWSKI T., PERSKI Z., RĄCZKOWSKI W., LASKOWICZ I., NESCIERUK P., GRABOWSKI D., KUŁAK M., WÓJCIK A. 2019 - Osuwiska w Polsce - od rejestracji do prognozy, czyli 13 lat projektu SOPO. Prz. Geol., 67 (5): 291-297. MAZUR S., ALEKSANDROWSKI P., SZCZEPAŃSKI J. 2010 - Zarys budowy i ewolucji tektonicznej waryscyjskiej struktury Sudetów (Outline structure and tectonic evolution of the Variscan Sudetes). Prz. Geol., 58: $133-145$.

MIGON P. 2010 - Nowe dane do poznania rzeźby osuwiskowej Gór Kamiennych. Przyr. Sud., 13: 215-224.

MIGOŃ P., PARZÓCH K. 2008 - Spływy gruzowe w Sudetach. Prz. Geogr., 80: 385-401.

MIGOŃ P., KASPRZAK M. 2011 - Morfologiczny zapis ruchów masowych na progach morfologicznych Gór Stołowych w świetle numerycznego modelu wysokości o dużej rozdzielczości. Przyr. Sud., 14: 115-124. MIGOŃ P., KASPRZAK M. 2016 - Pathways of geomorphic evolution of sandstone escarpments in the Góry Stołowe tableland (SW Poland) insights from LiDAR-based high-resolution DEM. Gemorph., 260: 51-63. MIGOŃ P., PLACEK A. 2014 - Litologiczno-strukturalne uwarunkowania rzeźby Sudetów. Prz. Geol., 64: 36-43.

MIGOŃ P., PÁNEK T., MALIK I., HRÁDECKÝ J., OWCZAREK P., ŠILHÁN K. 2010 - Complex landslide terrain in the Kamienne Mountains, Middle Sudetes, SW Poland. Geomorph., 124: 200-214.

MIGON P., JANCEWICZ K., KASPRZAK M. 2014a - Zasięg obszarów objętych osuwiskami w Górach Kamiennych (Sudety Środkowe) - porównanie map geologicznych i cyfrowego modelu wysokości z danych LiDAR. Prz. Geol., 64: 463-471.

MIGOŃ P., KACPRZAK A., MALIK I., KASPRZAK M. 2014b - Formy osuwiskowe w Górach Kamiennych (Sudety Środkowe) - kryteria identyfikacji i oceny zagrożeń. Land. Analys., 26: 39-60.

MIGON P., KACPRZAK A., MALIK I., KASPRZAK M., OWCZAREK P., WISTUBA M., PÁNEK T. 2014c - Geomorphological, pedological and dendrochronological signatures of a relict landslide terrain, Mt Garbatka (Kamienne Mts), SW Poland. Geomorph., 219: 213-231.

MIGOŃ P., JANCEWICZ K., RÓŻYCKA M., DUSZYŃSKI F. KASPRZAK M. 2017 - Large-scale slope remodelling by landslides Geomorphic diversity and geological controls, Kamienne Mts., Central Europe. Geomorph., 289: 134-151.

MIGOŃ, P., RÓŻYCKA, M., MICHNIEWICZ, A., KASPRZAK, M. 2015 - Identyfikacja form osuwiskowych na podstawie danych LiDAR wybrane przykłady z Sudetów Środkowych i Zachodnich. I Ogólnopolska Konferencja Osuwiskowa O!suwisko, 19-22 maja 2015, Wieliczka. Mat. konf.: $107-108$

MIEKOWSKI D., GÓRECKA A., WÓJCICKA-MILEWSKA M. 2008 Zabezpieczenie i monitoring osuwisk powstałych na Zboczu Północnym wyrobiska odkrywkowego BOT KWB Turów S.A. Kwart. AGH, 32 (2): 247-257.

MROZEK T. 2013 - Zagrożenie i ryzyko osuwiskowe w rejonie Szymbarku (Beskid Niski). Pr. Państw. Inst. Geol., 199: 5-40.

OBERC J. 1957 - Region Gór Bardzkich (Sudety). Przewodnik dla geologów. Wyd. Geol. Warszawa.

OBERC J., BADURA J., PRZYBYLSKI J., JAMROZIK L. 1996 Szczegółowa mapa geologiczna Sudetów w skali $1: 25$ 000, ark. Bardo Śląskie. Państw. Inst. Geol., Warszawa.
OSIKA A., WISTUBA M., MALIK I. 2018 - Relief evolution of landslide slopes in the Kamienne Mts. (Central Sudetes, Poland) analysis of high-resolution DEM from airbone LiDAR. Contemp. Trends. Geosci., 7 (1): 1-20

PARZÓCH K., MIGOŃ P. 2010 -Zdarzenia ekstremalne w systemie stokowym - grawitacyjne ruchy masowe i erozja gleb. [W:] Migoń P. (red.), Wyjatkowe zdarzenia przyrodnicze na Dolnym Ślasku i ich skutki. Rozpr. Nauk. IGiRR UWr., 14: 205-239.

PARZÓCH K., PAWLIK Ł., SOLARSKAA., WITEK M. 2012 - Osuwisko na stokach Średniaka w Masywie Śnieżnika Kłodzkiego w 2011 roku. Przyr. Sud., 15: 197-208.

PLACEK A. 2011 - Rzeźba strukturalna Sudetów w świetle wyników pomiarów wytrzymałości skał i analiz numerycznego modelu wysokości. Rozpr. Nauk. IGiRR UWr., 16: 1-190.

PULINOWA M. Z. 1972 - Procesy osuwiskowe w środowisku sztucznym i naturalnym. Dokumentacja Geograficzna, Inst. Geogr. PAN, Warszawa. PULINOWA M.Z., MAZUR R. 1971 - Stare osuwisko we wsi Grzmiąca w Sudetach. Wszechświat, 7-8: 200-202.

PULINOWA M. Z. 1989 - Rzeźba Gór Stołowych, Pr. UŚ1.

ROZPORZADZZENIE Ministra Środowiska z dnia 20 czerwca 2007 r. w sprawie informacji dotyczących ruchów masowych ziemi. Dz.U. 2007 nr 121 poz. 840

RÓŻYCKA M., MICHNIEWICZ A., MIGOŃ P., KASPRZAK M. 2015 - Identification and morphometric properties of landslides in the Bystrzyckie Mountains (Sudetes, SW Poland) based on data derived from airborne LiDAR. [W:] Jasiewicz J., Zwoliński Z., Mitasova H., Hengl T. (red.), Geomorphom. Geosci., 247-250.

RÓŻYCKA M., MIGOŃ P., MICHNIEWICZ A. 2016 - Topographic Wetness Index and Terrain Ruggedness Index in geomorphic characterisation of landslide terrains, on examples from the Sudetes, SW Poland. Zeitsch. Geomorph., 61 (2): 61-80.

SAWICKI L. 1995 - Mapa geologiczna regionu dolnośląskiego z przyległymi obszarami Czech i Niemiec 1 : 100000 (bez utworów czwartorzędowych). Państw. Inst. Geol., Warszawa.

SIKORA R., PIOTROWSKI A. 2017 - Związki wybranych form osuwiskowych w przełomowej dolinie Nysy Kłodzkiej w Górach Bardzkich ze struktura podłoża. [W:] Dłużewski i in. (red.), Streszczenia referatów i posterów. XI Zjazd Geomorfologów Polskich, 13-15 września 2017, Warszawa: 137.

SIKORA R., KOWALSKI A., PIOTROWSKI A. 2016a - Implikacje rozwoju osuwisk i zmienności geologicznej podłoża na izersko-kaczawskim odcinku doliny Bobru (Sudety Zachodnie). [W:] Wojewoda J (red.), Wyzwania polskiej geologii. 3. Polski Kongres Geologiczny, 14-18 września 2016. PTG, Wrocław: 348-350.

SIKORA R., KOWALSKI A., BADURA J., GOTOWAŁA R., PIOTROWSKI A., RÓŻAŃSKI P., URBAŃSKI K. 2016b - Wybrane osuwiska Dolnego Śląska i ich związek z budową geologiczna. [W:] Wojewoda J., Kowalski A. (red.), Wyzwania polskiej geologii. Przewodnik do wycieczek kongresowych. 3. Polski Kongres Geologiczny, 14-18 września 2016. PTG, Wrocław: 44-60.

SIKORA R., WOJCIECHOWSKI T., TOMASZCZYK M., PIOTROWSKI A. 2017 - Geological condition of landslides occurrence in the Bardzkie Mountains and adjacent areas (Sudetes, SW Poland). $4^{\text {th }}$ World Landslide Forum, Lubljana, Slovenia.

SOLON J., BORZYSZKOWSKI J., BIDŁASIK M., RICHLING A., BADORAK., BALON J., BRZEZIŃSKA-WÓJCIK T., CHABUDZIŃSKI Ł., DOBROWOLSKI R., GRZEGORCZYK I., JODŁOWSKI M., KISTOWSKI M., KOT R., KRAZŻ P., LECHNIO J., MACIAS A., MAJCHROWSKA A., MALINOWSKA E., MIGOŃ P., MYGA-PIAKTEK U., NITA J., PAPIŃSKA E., RODZIK J., STRZYŻ M., TERPILOWSKI S., ZIAJA W. 2018 - Physico-geographical mesoregions of Poland: Verification and adjustment of boundaries on the basis of contemporary spatial data. Geogr. Pol., 2 (91): $143-170$.

SYNOWIEC G. 2003a - Formy osuwiskowe w Górach Kamiennych. Prz. Geol., 51: 59-65.

SYNOWIEC G. 2003b - Structural landslides in the Kamienne Gory Mts., Sudetes, SW Poland. [W:] Rybař J., Stemberk J., Wagner G.(red.), Landslides. Swets \& Zeitlinger, Lisse: $311-314$.

SZWARNOWSKI A., KACZAREWSKI T. 2008 - Osuwisko Świniec. Przebieg zagrożenia, akcja ratownicza i likwidacja skutków. Mies. WUG, 8 (97): 11-20.

WOJCIECHOWSKI T. 2019 - Podatność osuwiskowa Polski. Prz. Geol., 67 (5): $320-325$.

WOJEWODA J., KOWALSKI A. 2016 - Rola południowo-sudeckiej strefy ścinania w ewolucji Sudetów. [W:] Wojewoda J., Kowalski A. (red.), Wyzwania polskiej geologii. Przewodnik do wycieczek kongresowych. 3. Polski Kongres Geologiczny, 14-18 września 2016. PTG, Wrocław: 44-60.

ZIĘTARA T. 1968 - Rola gwałtownych ulew i powodzi w modelowaniu rzeźby Beskidów. Pr. Geogr. IG PAN, 60.

ŻURAWEK R. 1999 - Zmiany erozyjne w dolinach rzek Sudetów Kłodzkich wywołane powodziami w lipcu 1997 r. oraz w lipcu 1998 r. Probl. Zagos. Ziem Gór., 45: 43-61. 